\title{
Modeling of the Black Sea Region Climate Changes in the XXI Century
}

\author{
V.V. Efimov', E.M. Volodin ${ }^{2}$, A.E. Anisimov ${ }^{1}$ \\ ${ }^{1}$ Marine Hydrophysical Institute, Russian Academy of Sciences, Sevastopol, \\ Russian Federation \\ e-mail:vefim38@mail.ru \\ ${ }^{2}$ Institute of Numerical Mathematics, Russian Academy of Sciences, \\ Moscow, Russian Federation \\ e-mail:volodin@inm.ras.ru
}

\begin{abstract}
Numerical experiments on producing regional projections of climate changes in the Black Sea region in the end of the XXI century are performed. The regional numerical climate model HadRM3P and input data of the atmosphere-ocean general circulation global model INMCM4 (Institute of Numerical Mathematics, Russian Academy of Sciences) are used. Application of the regional model permits to reproduce mesoscale climate processes and to obtain new numerical estimates of regional climate changes with high spatial resolution which supplement large-scale assessments with new values. Changes of temperature and precipitation seasonal values in the future 2071 - 2100 period are compared with those of the control period in $1971-2000$. According to the INMCM4 model, temperature in the Black Sea region will increase by $2.5-3^{\circ} \mathrm{C}$ in winter and $4-4.5^{\circ} \mathrm{C}$ in summer. In summer it will be accompanied by precipitation decrease up to $40 \%$. For the territory of Ukraine and the central European part of Russia, the regional model produces more pronounced temperature growth in summer: up to 25 - $30 \%$. The regional model forecast of summer precipitation changes in Ukraine and in the Balkan Peninsula is 30\% lower than the analogous forecast of the global model. The obtained projections of climate changes in the Black Sea region can be considered as quite unfavorable for the agricultural sector.
\end{abstract}

Keywords: the Black Sea region, temperature, precipitation, climate change, climate modeling.

DOI: 10.22449/1573-160X-2015-2-3-13

(C) 2015, V.V. Efimov, E.M. Volodin, A.E. Anisimov

(C) 2015, Physical Oceanography

Introduction. Over the past 100 years global temperature on the Earth increased by $0.8-1.0{ }^{\circ} \mathrm{C}$. Nowadays it is ascertained that the cause of global warming is an anthropogenic factors impact (primarily the increase of greenhouse gases concentration) [1, 2]. At the present time the numerical assessments (scenarios) of the Earth climate changes, obtained by means of up-to-date global climate models, which describe an atmosphere - ocean - glaciers - the land upper layer interrelated system and take into account the impact of external nature factors (volcanic activity, changes of solar constant and so on), and also of anthropogenic impact, are known. Besides, the anthropogenic impact is considered by the assignment of probable greenhouse gases and other chemical components emission scenarios determining total greenhouse effect. However, the assessments of XXI century supposed climate changes calculated by the global atmosphere-ocean general circulation models (GAOGCM) sufficiently differ in some areas of the world.

Existing global climate numerical models still have insufficient spatial resolution (in general, more than $100 \mathrm{~km}$ ) and that's why they do not take into account the effect of local features determining the local climate (such as seas, mountains, underlying surface properties). It is fully applicable to the Black Sea region, which 
has a complicated shoreline and the high Caucasian, the Crimean and the Pontic Mountains. The Crimean Mountains were not considered in the existing climate models, the Caucasian Mountains altitude did not exceed $2 \mathrm{~km}$, and the whole Black Sea was determined by less than 10 points of computational domain. So, within the framework of climate change general problem study an important aim is the regionalization, i. e. a shift from large-scale global field calculation to the regional assessments, which are performed to obtain the characteristics of regional climate (temperature, precipitation, humidity, wind velocity etc.) considering the effect of regional factors.

Methodology. Among all known regionalization methods the most developed is a dynamical method based on the usage of atmosphere circulation numerical models with high spatial resolution and input data of large-scale global modeling. Thus, our aim is to recalculate the data obtained in atmosphere circulation models with large-scale resolution to the spatial grid with higher resolution by means of numerical model where all small-scale features of underlying surface (which are absent in the basic global climate model) are considered. Necessary condition of such approach is a high quality of global modeling input data and of the regional atmosphere circulation numerical model itself.

Recently, it could be observed the increasing number of works on regional projections of climate change. Particularly, for the European continent the most well-known projects are Prediction of Regional scenarios and Uncertainties for Defining EUROPEAN Climate change risks and Effects (PRUDENCE) [3], Ensemble-Based Predictions of Climate Changes and Their Impacts (ENSEMBLES) [4], A Coordinated Regional Downscaling Experiment (CORDEX) [5]. However, the climate change in the Black Sea region, as a rule, is beyond the attention of the authors. Nevertheless, we should mention some of the work where such data are presented. In the works $[6,7]$ the numerical assessments of the regional climate changes in Ukraine and the Black Sea region for the end of XXI century using the regional climate model HadRM3P [8] and the data of $\operatorname{Had} A M 3 P$ large-scale atmosphere circulation model [9] with $\sim 200 \mathrm{~km}$ resolution are presented. Spatial distributions of temperature and precipitation changes for winter and summer periods were obtained. As the basic results for the territory of Ukraine a sufficient increase of air temperature climatic values in all seasons and a sufficient decrease of summer precipitation were noted. In a series of works [10 - 12] there are represented the assessments for the Black Sea region, the Caucasus and the Anatolian Peninsula, but the territory of Ukraine is located on the boundary of spatial domain and it is difficult to make clear conclusion about climate change in this region.

In this work the results of climate change numerical modeling in the Black Sea region using the same regional atmosphere circulation model and the new largescale modeling data obtained from the new GAOGCM model - INMCM4 of Institute of Computational Mathematics, Russian Academy of Sciences [13] are given. INMCM4 numerical model is the only fourth-generation model developed in the CIS, which is a part of international project Coupled Model Intercomparison Project Phase 5 (CMIP5) [14]. Climate model consists of two main blocks - general atmosphere circulation and general ocean circulation models. In the atmosphere model three-dimensional hydrothermodynamic equations are solved using the finite-difference method in hydrostatic approximation. In finite-difference scheme the mass, humidity and momentum preservation law is implemented. Spa- 
tial resolution in the atmosphere module is $2 \times 1.5^{\circ}$. The atmosphere model is vertically divided into $21 \sigma$-levels with $10 \mathrm{hPa}$ upper limit and $5 \mathrm{~min}$ time-step. The model includes the schemes of radiation parameterization, deep and shallow convection, turbulent mixing in the boundary layer, orographic and non-orographic gravity-wave resistance and also the schemes of soil and vegetation processes [15].

INMCM4 model also includes an up-to-date ocean circulation block, which is especially important for sea climate reproduction and particularly for the Black Sea region. Spatial resolution in the ocean model is $1 \times 0.5^{\circ}$ by longitude and latitude and 40 levels vertically. Time step is 2 hrs and the internal step for temperature and salinity advection is $30 \mathrm{~min}$. During the interaction of models the heat flows, fresh water flows and friction induced stress are transferred from the atmosphere to the ocean, and surface temperature and sea ice area - from the ocean to the atmosphere. Flow correction is not used.

To construct the climate change projections the time-slice approach was used. The changes of climate characteristics had been calculated as the difference between their values in two model periods (both with 30 years duration). For 2071 2100 years future period model parameterization schemes were formulated taking into account the concentration changes of greenhouse gases $\left(\mathrm{CO}_{2}, \mathrm{CH}_{4}, \mathrm{~N}_{2} \mathrm{O}, \mathrm{O}_{3}\right)$ and sulfate aerosol according to one of the common scenarios of greenhouse gas emissions - "adverse" scenario RCP8.5 [16]. For 1971 - 2000 check period the concentrations were set in accordance with observations.

Large-scale climate changes. At first we should consider the large-scale changes of European climate for 2071 - 2100 years period in relation to 1971 2000 years check period. These changes are described by the INMCM4 modeling data, which are the input data for HadRM3P regional model. Besides, we should focus on two principle climate parameters - near-surface air temperature averaged by 30 -years period and precipitation.

Air temperature. Temperature changes of near-surface air layer in $2071-2100$ years period and 1971 - 2000 years check period for two seasons are represented in Fig. 1.

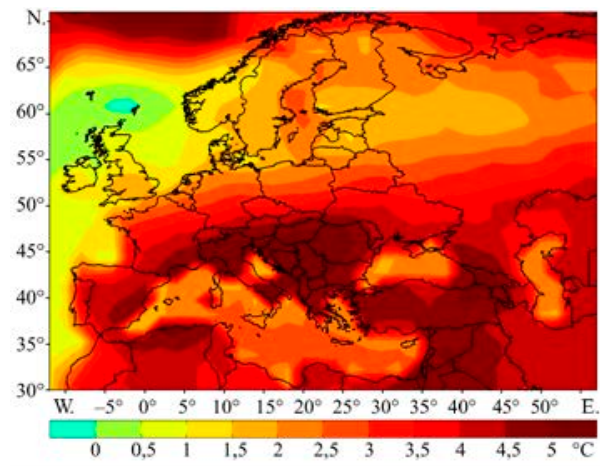

$a$

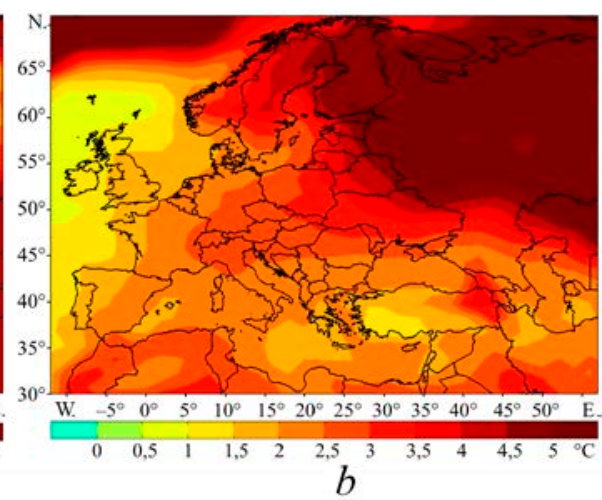

Fig. 1. Near-surface air temperature change $\left({ }^{\circ} \mathrm{C}\right)$ according to INMCM4 model data in $2071-2000$ years future climate according to 1971 - 2000 check period for summer (a) and winter $(b)$

They are characterized by a significant warming in summer (June, July and August) and in winter (December, January, February) seasons. At the same time, these 
temperature change distribution patterns on European continent significantly differ for summer and for winter. In winter the maximum warming occurs in central and northern parts of Russia (up to $5{ }^{\circ} \mathrm{C}$ ). In summer, on the contrary, the most intensive warming may be observed in the Balkan Peninsula, the Anatolian Peninsula and the Middle East. Temperature increase over the land is much more than warming over the sea in both seasons. Generally, the temperature change distributions correlate well with the assessments obtained by the ensemble of global models [1, 2]: INMCM4 model belongs to the series of models with close-to-average sensitivity (by the ensemble) to external perturbations. The given assessments are rather close to ones represented in the work [6].

Precipitation. In Fig. 2 large-scale changes of precipitation values for the same period of summer and winter are represented. Comparing the shown distributions with multi-model data [1] we are able to make a conclusion about their qualitative correspondence (they differ quantitatively because the precipitation distributions in [1] are given for "adverse" RCP4.5 emission scenario and instead of three months seasons there were used six months periods). In Fig. 2, $a$ in summer period the well-marked Mediterranean precipitation decrease area (more than $50 \%$ decrease) and the area of small increase for several regions of the Northern Europe land part (up to $\sim 30 \%$ increase) are visible. We should mention that such pattern of precipitation changes in Europe is also typical for the results obtained by many other models [1, 2]. More dry and arid climate of the Mediterranean region was mentioned by many authors [17 - 20]. For winter period (Fig. 2, b) the Mediterranean precipitation decrease area and the area of increased precipitation in the land part of Northern Europe ( 10 \% increase) are marked out lesser.
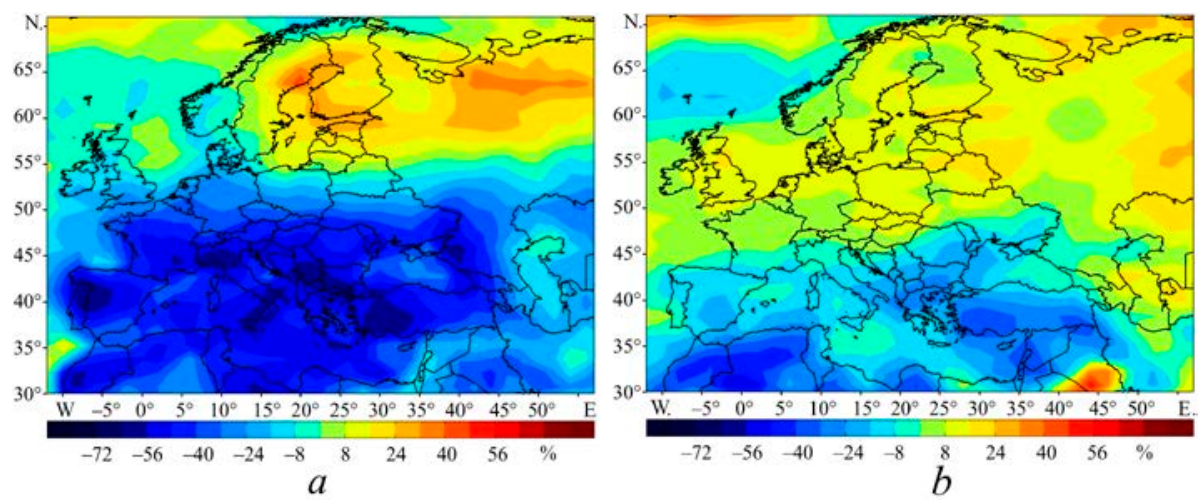

Fig. 2. Precipitation quantity change (\%) according to INMCM4 model data in $2071-2100$ years period in comparison with 1971 - 2000 control period for summer $(a)$ and winter $(b)$

The represented distributions of temperature and precipitation climatic changes for late XXI century obtained using the global numerical model don't describe more small-scale processes of climatic variability. They may be considered as a background against which the regional features should appear during the modeling using a regional numerical model.

Regional features of climate change. As it was mentioned, the increased spatial resolution of regional model allows us to reproduce the effect of mountains, 
small-scale features of sea basins, underlying surface properties on atmospheric processes. The distinguishing of their contribution could be considered as the main expecting result of regional modeling. Though, even afar from coast and mountains the calculating atmospheric fields may differ from the input large-scale models. The cause of this process are differences in physical processes parameterization in global and regional models or the possibility of more small-scale motion in regional model with increased resolution in comparison with the global one. For instance, in the work [21] it was pointed out that the regionalization on an average leads to the weakened warming and to greater quantity of precipitation (in those regions where the precipitation quantity increases) in comparison with the results by the global models.

Now we should logically examine the calculation results of regional climatic changes, i. e. difference fields between the future and check periods for two seasons and for the same parameters - temperature and precipitation. Besides, we will also calculate the regional modeling climatic effects (RMCE) determined as a difference of change fields for $2071-2100$ years towards $1971-2000$ control period obtained by INMCM4 large-scale model (an input data of regional model) and the same change fields calculated by regional model. The RMCE fields, determined this way, allow us to evaluate the result of regional model usage during the calculation of future climate in comparison with its evaluation by the global model, i. e to distinguish clearly the effects of climatic changes of regional modeling.

Air temperature. In Fig. 3 the average near-surface air temperature distributions in the Black Sea region are represented. In summer (Fig. 3, a) the maximum temperature increase is observed in central and western parts of domain. In the most part of the region, except the Crimea and the southern coastal area, it is 4.5 $5{ }^{\circ} \mathrm{C}$. Above the water areas of the Black Sea, the Caspian Sea and in coastal areas the warming is less noticeable (within $3-3.5^{\circ} \mathrm{C}$ ). This fact is explained by the impact of water basins, which play the role of stabilizing factor. In the area of the Asia Minor and in land area, which is located westward of the Black Sea (Balkan Peninsula) the calculations by the model show the most intensive warming, up to $5.5-6{ }^{\circ} \mathrm{C}$.
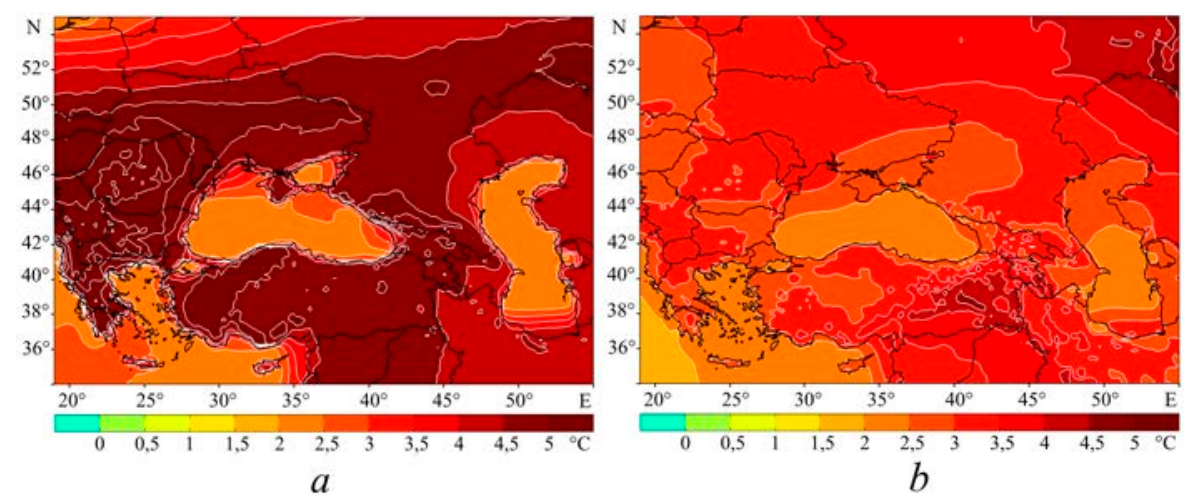

Fig. 3. Near-surface air temperature change $\left({ }^{\circ} \mathrm{C}\right)$ according to data of HadRM3P model in $2071-2100$ years future climate in comparison with 1971 - 2000 check period for summer $(a)$ and winter $(b)$ 
For winter season (Fig. 3, $b$ ) the warming assessments are more moderate. The most intensive warming is observed in the north-east part of the domain, maximal value is $4{ }^{\circ} \mathrm{C}$. Above the sea and in the southern part of domain it is $\sim 2.5-3{ }^{\circ} \mathrm{C}$.

Thus, the warming value in winter is greater than in summer. Such an asymmetry may be explained by the effect of positive feedback between the snow mantle and the air temperature in a climatic system: as a result of earlier snow thaw, in summer the soil dampness and reflectance (albedo) decrease, and properly increases the air temperature. Without giving the data, we just point out that the number of winter days with positive air temperature increases.

In Fig. 4 distribution features of RMCE fields, i. e. the effects distinguishing as the result of regional model usage are given. It is obvious that there were appeared some features, which are absent in Fig. 1, 2. In summer the Balkan Peninsula and almost the whole northern part of spatial domain are occupied with the area of increased temperature values - up to $1.4^{\circ} \mathrm{C}$. The usage of the model for coastal areas of the Black Sea and the Caspian Sea leads, on the contrary, to the reduced signal of temperature increase. The usage of regional model allows us to obtain other results. For mountainous regions of Turkey and Transcaucasia the greatest RMCE values are obtained in temperature fields - up to $2^{\circ} \mathrm{C}$, i. e., under $40 \%$ of summarized warming in this area. Positive anomalies were distinguished also at the Northern Caucasus and the Balkans - their values are $\sim 1{ }^{\circ} \mathrm{C}$. In spacious zones of northern parts of calculated area RMCE values are, on the contrary, negative, in some areas a cold spell reaches $-1.4^{\circ} \mathrm{C}$.
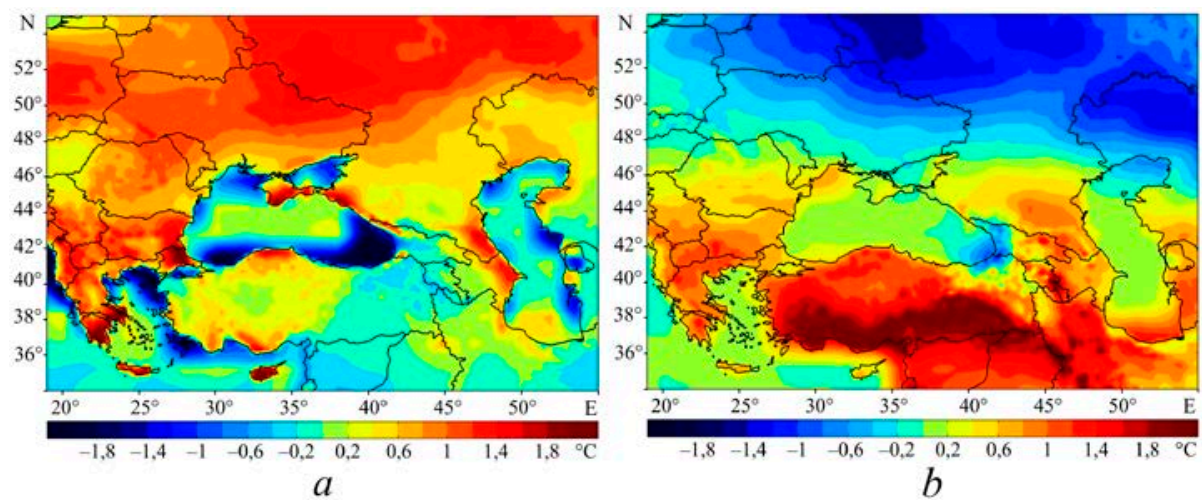

Fig. 4. Difference of near-surface air temperature $\left({ }^{\circ} \mathrm{C}\right)$ in $2071-2100$ years future climate in comparison with 1971 - 2000 control period according to the data of HadRM3P and INMCM4 models for summer $(a)$ and winter $(b)$

The causes of such regional modeling effects are closely connected with parameterization features of physical processes in HadRM3P, which differ from ones in INMCM4 model. Giving no illustrations, we just notice that one of the main indicators of precipitation field changes and, lesser, of air temperature are features of cloudiness reproduced in accordance with the model. At the same time, cloudiness is not the only cause of RMCE occurrence because the differences in reproduction of climatic effects and feedback of physical mechanisms in global and regional models are, obviously, quite significant. Their study requires special analysis and additional calculations by sensitivity. 
Precipitation. In Fig. 5 the seasonal changes of precipitation quantity obtained according to regional modeling data are shown. Unlike the temperature, the precipitation rate change in annual cycle is more complicated. In summer (Fig. 5, a) the precipitation quantity decreases all over the spatial domain i. e., the summer becomes more arid: precipitation quantity decreases by $50-60 \%$ (more than according to INMCM4 data).

In winter (Fig. 5, $b$ ) a considerable precipitation decrease is observed only for the Anatolian Peninsula and surrounding areas of the Mediterranean Sea. In other parts of the region the precipitation change is less pronounced. There are distinguished several small-scale areas related to the relief inhomogeneity or coastline contours. Maximum precipitation increase (up to $25 \%$ ) is observed in the region of the Caspian Sea basin. Generally, it could be noted a close relative precipitation change in winter period according to regional model and INMCM4 model data.
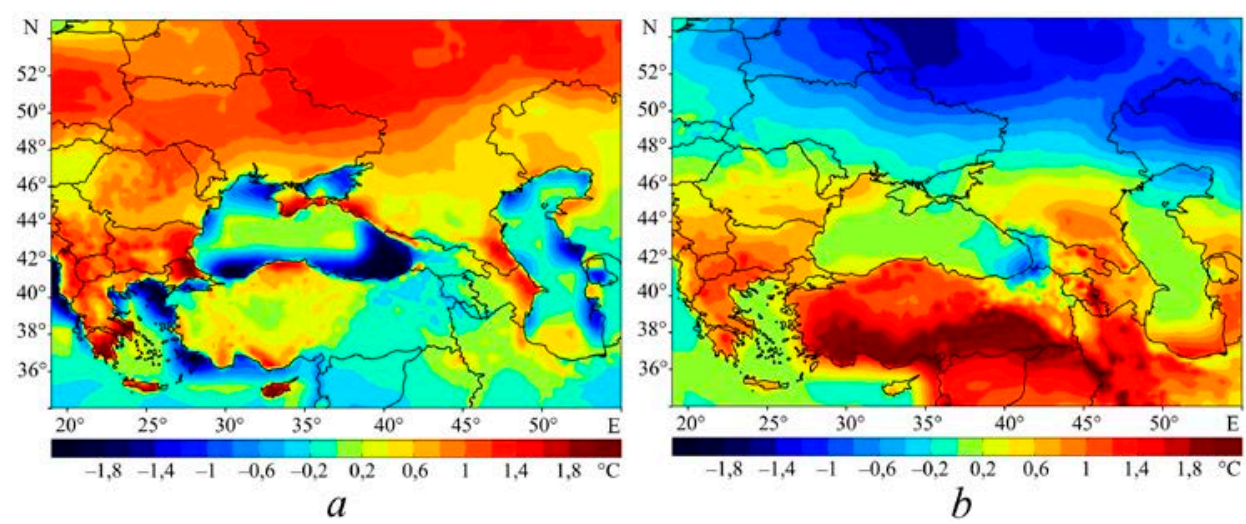

Fig. 5. Change of precipitation quantity (\%) according to HadRM3P model data in $2071-2100$ future climate comparing with 1971 - 2000 years control period for summer $(a)$ and winter $(b)$

In Fig. 6 the seasonal RMCE values for the projection of precipitation quantity change are represented. In this case the RMCE fields had been calculated as absolute values of precipitation quantity change difference by regional and global models. RMCE values for precipitation in summer period (Fig. 6, a) by the absolute value is generally lesser, than in winter. The usage of regional model for the territories of Ukraine, the Crimea and the Balkans leads to additional precipitation quantity decrease, up to $10 \mathrm{~mm} \cdot \mathrm{month}^{-1}$. It makes $30-40 \%$ of the precipitation decrease according to INMCM4 data. In the rest part of spatial domain there are distinguished several RMCE local maximums, but in general, their values are small. It is interesting to mention that, despite of the small RMCE absolute values, relative precipitation changes according to HadRM3P data are substantially larger than according to the global modeling data, even where the RMCE values are positive (Fig. 5, a). Without introducing the data, we just mention that it can be explained by some precipitation underestimation by regional model in control and future periods.

In the winter months (Fig. 6, $b$ ) the RMCE values are more heterogeneous, but, nevertheless, sufficient in comparison with global model signal. A slight additional precipitation decrease takes place in the northern areas of the spatial domain PHYSICAL OCEANOGRAPHY NO. 2 (2015) 
in the regional model. At the mainland part of the Anatolian Peninsula and in the western Black Sea region precipitation decrease is less pronounced. It can be seen also in Fig. 5, $b$ - in several mentioned areas the precipitation decrease in regional model is practically leveled. Maximum RMCE values are distinguished in mountainous regions where high resolution of regional model allows to consider the local features of orography. Thus, both large-scale and regional atmospheric processes contribute to the precipitation change in summer and winter. RMCE values in both seasons have a significant spatial inhomogeneity, which manifests itself in a noticeable impact mesoscale processes.
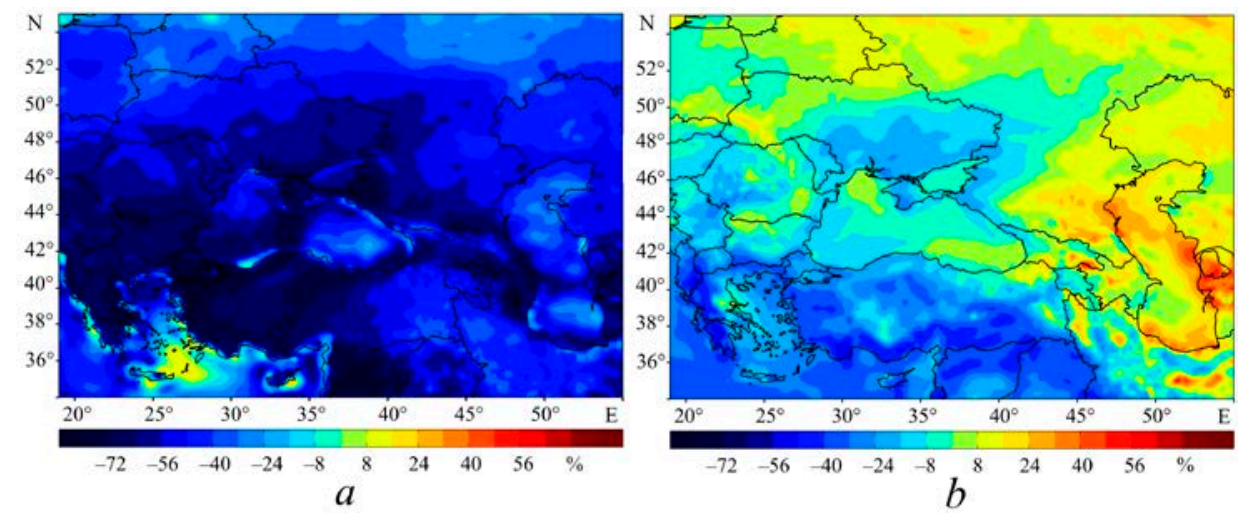

Fig. 6. Difference of precipitation quantity change $\left(\mathrm{mm} \cdot \mathrm{month}^{-1}\right)$ in $2071-2100$ years future climate in comparison with $1971-2000$ control period according to HadRM3P and INMCM4 for summer (a) and winter $(b)$

There were considered only two major climate parameters - air temperature and precipitation, which are of the greatest interest. The given work presents only general assessments of the results. The detailed analysis of all the regional features of temperature and precipitation change requires separate consideration. During the numerical experiments there were obtained the change assessments by the end of the XXI century and other climate characteristics such as pressure, wind, humidity, cloudiness, heat and radiation flows etc. The changes for some of them for Ukraine in the XX century are given in the work [22]. Comparison of changes calculated for the XX century and for the end of the XXI century shows that future climate changes generally correspond to the climate shifts, which took place in the second part of XX century, but they are several times greater. For example, during the second half of the XX century the average winter temperature in Ukraine has increased by $1-1.5{ }^{\circ} \mathrm{C}$, which is $2-3$ times less than obtained numerical assessments of future changes. A significant decrease of average seasonal summer precipitation, amounting $\sim 50 \%$ in the late XXI century, simultaneously with $5-6{ }^{\circ} \mathrm{C}$ air temperature increase are particularly unfavorable.

The results of our numerical regional experiments generally correlate with known published data of climate regional modeling for Central and Western Europe. In accordance with most models, the tendency of climate warming in the end of XX century will continue also in the XXI century and in European region it is more intensive than on the average in the world [1, 2]. As it was mentioned, the 
models are consistent in the tendency of precipitation increase in winter in Northern Europe and their decrease in summer in Southern Europe. Possible causes of such a difference are associated with the increase of temperature contrasts between the land and the ocean, shear of large-scale circulating systems, feedback in the atmosphere - the land system $[23,24]$. The Black Sea region usually went beyond the framework of known numerical calculations. The feature of our experiments consists in the fact that there were performed the numerical calculations of climate change scenarios and the quantitative assessments were obtained directly for the Black Sea basin.

Conclusion. The numerical assessments of climate change in the Black Sea region for the end of XXI century using HadRM3P regional climate model and the input data of the atmosphere-ocean general circulation global model INMCM4 (Institute of Numerical Mathematics, Russian Academy of Sciences) were obtained. The regional model allowed us to reproduce the atmospheric circulation in the Black Sea region with increased spatial resolution and to obtain regional projections of climate changes. New numerical assessments of these changes consider mesoscale processes in the Black Sea region thereby making a contribution to large-scale fields obtained according to INMCM4 model data.

Thus, according to INMCM4 model and RCP8.5 scenario temperature mode change in the end of the XXI century in the Black Sea region is characterized by sufficient warming: by $2.5-3^{\circ} \mathrm{C}$ in winter and $4-4.5^{\circ} \mathrm{C}$ in summer. In summer period precipitation quantity decreases all over the Black Sea region and Southern Europe (up to $50 \%$ ) and increases in Northern Europe (up to 30). In winter season the precipitation change is less pronounced. In its turn, regional model introduces significant changes to these fields. First of all, due to the integration of mesoscale circulation and interaction with the underlying surface features, regional modeling allowed us to obtain more detailed projections of climate change in areas with a complicated relief and coastline, with distinguishing the effects which are absent in the input data. As a result, a considerably greater warming was obtained for the summer period in the Balkan region, in Ukraine and in the center of the European part of Russia, where the anomalies were under $1.4{ }^{\circ} \mathrm{C}$ i. e., $~ 25-30 \%$ of the total warming in this region; on the contrary, according to the regional model, winter is characterized by smaller warming in the northern parts of calculated domain and by more intensive warming (up to $2{ }^{\circ} \mathrm{C}$ ) - in the Anatolian peninsula. Precipitation change projections also change: in summer due to the usage of regional model precipitation in some regions decrease much greater (up to $30 \%$ ) than according to data of global model; inhomogeneous regional anomalies in general are observed precipitation change fields in winter. The obtained projections of climate changes in the Black Sea region can be considered as quite unfavorable for the agricultural sector.

Acknowledgements. The present research was carried out under the financial support of Russian Foundation for Basic Research and State Fund for Fundamental Research of Ukraine joint project No. F53/95-2013 applying the PRECIS software kindly provided by Met Office Hadley Centre (Great Britain). 


\section{REFERENCES}

1. Climate Change 2007: The Physical Science Basis. Contribution of Working Group I to the Fourth Assessment Report of the Intergovernmental Panel on Climate Change, Eds. S. Solomon, D. Qin, M. Manning [et al.], Cambridge, United Kingdom and New York, NY, USA: Cambridge Univ. Press, 996 p.

2. Climate Change 2013: The Physical Science Basis. Working Group I Contribution to the IPCC Fifth Assessment Report (AR5), Eds. T.F. Stocker, D. Qin, G.-K. Plattner [et al.], Cambridge, United Kingdom and New York, NY, USA: Cambridge Univ. Press, 1535 p.

3. Christensen, J.H., Christensen, D.B., 2006, "A summary of the PRUDENCE model projections of changes in European climate by the end of this century”, Clim. Change, vol. 81, no. 1, pp. 7-30.

4. ENSEMBLES: Climate Change and its Impacts: Summary of research and results from the ENSEMBLES project, Eds. P. van der Linden, J.F.B. Mitchell, UK, Exeter: Met Office Hadley Centre, $160 \mathrm{p}$.

5. Jacob, D., Petersen, J., Eggert, B., 2014, "EURO-CORDEX: new high-resolution climate change projections for European impact research”, Reg. Env. Change, vol. 14, no. 2, pp. 563578.

6. Efimov, V.V., Ivanov, V.A. \& Anisimov, A.E., 2011, “Chislennoe modelirovanie izmeneniya klimata Ukrainy $v$ XXI veke [Numerical evaluations of the precipitation changes in the Black Sea region of Ukraine in XXI century]”, Dop. NAN Ukraini, no. 3, pp. 100-107 (in Russian).

7. Anisimov, A.E., Efimov, V.V., 2012, “Chislennye otsenki izmeneniya osadkov v Chernomorskom regione Ukrainy $v$ XXI stoletii [Numerical evaluations of the precipitation changes in the Black Sea region of Ukraine in XXI century]”, Morskoy gidrofizicheskiy zhurnal, no. 6, pp. 45-58 (in Russian).

8. Jones, R.G., Noguer, M. \& Hassel, D.C. [et al.], 2004, “Generating high resolution climate change scenarios using PRECIS”, UK, Exeter: Met Office Hadley Centre, 40 p.

9. Rowell, D.P., 2005, "A scenario of European climate change for the late twenty-first century: seasonal means and interannual variability”, Clim. Dyn., vol. 25, no. 7-8, pp. 837-849.

10. Önol, B., H.M. Semazzi, F., 2009, "Regionalization of climate change simulations over the Eastern Mediterranean”, J. Clim., vol. 22, no. 8, pp.1944-1961.

11. Bozkurt, D., Turuncoglu, U. \& Sen, O.L. [et al.], 2012, "Downscaled simulations of the ECHAM5, CCSM3 and HadCM3 global models for the Eastern Mediterranean-Black Sea region: evaluation of the reference period”, Clim. Dyn., vol. 39, no. 1-2, pp. 207-225.

12. Önol, B., Bozkurt, D. \& Turuncoglu, U.U. [et al.], 2014, "Evaluation of the twenty-first century RCM simulations driven by multiple GCMs over the Eastern Mediterranean-Black Sea region”, Clim. Dyn., 2014, vol. 42, no. 7-8, pp. 1949-1965.

13. Volodin, E.M., Dianskii, N. A., Gusev, A.V., 2010, "Vosproizvedenie sovremennogo klimata s pomoshch'yu sovmestnoy modeli obshchey tsirkulyatsii atmosfery i okeana INMCM4 [Contemporary climate representation by means of atmosphere and ocean combined circulation model INMCM4]”, Izv. RAN. Fizika atmosfery i okeana, vol. 46, no. 4, pp. 379-400 (in Russian).

14. Taylor, K.E., Stouffer, R.J. \& Meehl, G.A., 2012, “An overview of CMIP5 and the experiment design”, Bull. Amer. Met. Soc., vol. 93, no. 4, pp.485-498.

15. Volodin, E.M., Lykosov, V.N., 1998, "Parametrizatsiya protsessov teplo- i vlagoobmena v sisteme rastitel'nost'-pochva dlya modelirovaniya obshchey tsirkulyatsii atmosfery 1 . Opisanie i raschety s ispol'zovaniem lokal'nykh dannykh nablyudeniy [Parameterization of the warmth and humidity change in the processes in the vegetation-soil system for atmosphere general circulation modeling. 1. Description and calculations applying local observation data]”, Izv. RAN. Fizika atmosfery i okeana, vol. 34, no. 4, pp. 453-465 (in Russian).

16. Moss, R.H., Edmonds, J.A., Hibbard, K.A. [et al.], 2010, “The next generation of scenarios for climate change research and assessment”, Nature, vol. 463, no. 7282, pp. 747-756. 
17. Gao, X., Giorgi, F., 2008, "Increased aridity in the Mediterranean region under greenhouse gas forcing estimated from high resolution simulations with a regional climate model”, Glob. Planet. Change, vol. 62, no. 3, pp. 195-209.

18. Giorgi, F., 2006, “Climate change hot-spots”, Geophys. Res. Lett., vol. 33, no. 8, L08707, doi: 10.1029/2006GL025734.

19. Sheffield, J., Wood, E.F., 2008, "Projected changes in drought occurrence under future global warming from multi-model, multi-scenario, IPCC AR4 simulations”, Clim. Dyn., vol. 31, no. 1 , pp. 79-105.

20. Heinrich, G., Gobiet, A., 2012, "The future of dry and wet spells in Europe: A comprehensive study based on the ENSEMBLES regional climate models”, Int. J. Climatol., vol. 32, no. 13, pp.1951-1970.

21. Heinrich, G., Gobiet, A., Mendlik, T., 2014, "Extended regional climate model projections for Europe until the mid-twenty first century: combining ENSEMBLES and CMIP3”, Clim. Dyn., 2014, vol. 42, no. 1-2, pp. 521-535.

22. Efimov, V.V., Gubanova, E.V., 2003, “Izmenenie klimata Ukrainy v XX veke”, Sevastopol, 42 p. (in Russian).

23. Rowell, D.P., Jones, R.G., 2006, "Causes and uncertainty of future summer drying over Europe”, Clim. Dyn., vol. 27, no. 2-3, pp. 281-299.

24. Kendon, E.J., Rowell, D.P., Jones, R.G., 2010, "Mechanisms and reliability of future projected changes in daily precipitation”, Clim. Dyn., vol. 35, no. 2-3, pp. 489-509. 